\title{
Implementation of Industrial Work Character Development in Teaching and Learning Process in Vocational High Schools
}

\author{
*Herlambang Sigit Pramono, Department of Electrical Engineering Education, Yogyakarta State University, \\ Indonesia, herlambang@uny.ac.id \\ Soenarto, Department of Technical and Vocational Education, Yogyakarta State University, Indonesia \\ Putu Sudira, Department of Technical and Vocational Education, Yogyakarta State University, Indonesia \\ Nur Azizah, Department of Electrical Engineering Education, Yogyakarta State University, Indonesia \\ ${ }^{*}$ Corresponding Author
}

\begin{abstract}
This study aims to determine the implementation of work character development and the factors that influence industry-based work character development in vocational students. This research was conducted at 4 Vocational High Schools (SMK), namely SMK Muhammadiyah Prambanan, SMK N 2 Pengasih, SMK N 4 Semarang and SMK N 7 Semarang with a mixed method countenance evaluation model and analyzed with an explanatory sequential design. This research is a case study research. The results showed that the development of work character in teaching and learning activities at Vocational High Schools seen from the antecedent's aspect, the transaction aspect, and the outcomes aspect were in very good categories. The factors that influence industry-based work character development for vocational high school students are divided into 2, namely internal factors and external factors. Internal factors include family environmental factors, school environment, facilities and infrastructure, teacher and student factors. While external factors here, in the form of soft skills possessed by students, including: religion, honesty, time discipline, responsibility, enthusiasm, and mutual respect.
\end{abstract}

Keywords: Evaluation, Countenance Stake, Vocational High School (SMK)

Received: 04.12.2020 $\quad$ Accepted: 10.01.2021 $\quad$ Published: 05.02.2021

\section{INTRODUCTION}

Vocational High School (SMK) is a form of formal education unit that organizes vocational education at the secondary education level. This vocational secondary education prioritizes the development of students' abilities to carry out certain types of work (Republic of Indonesia Government Regulation Number 29 of 1990). The fact is that, currently the workforce produced by SMK is still not able to meet the labor requirements that meet the qualifications required by the world of work. The gap between the ability of SMK graduates and the needs of the industry has resulted in many SMK graduates being unemployed. SMK is the largest contributor to the Open Unemployment Rate (TPT) in Indonesia compared to other education levels. Based on data from the Indonesian Central Bureau of Statistics (BPS, 2019), the TPT for SMK graduates is: 11.41\% (August 2017), 8.92\% (February 2018), 11.24\% (August 2018), 8.63\% (February 2019), $10.42 \%$ (August 2019), and 8.49\% (February 2019). Wibowo (2016) states that SMK as one of the important role holders in preparing the workforce, is required to always be able to follow the needs of the growing market. SMK is required to produce graduates who are good at hard skills and soft skills.

Hanafi (2012) states that the world of work, in this case industry, complains that many SMK graduates have skills that are not in accordance with those needed by the industry, especially 'employability' to be able to survive in various conditions and work situations that can change at any time. What is expected from SMK graduates is to have a balance of academic skills, technical skills, and employability skills. Employment skills are skills, knowledge, and competencies that will improve the ability of workers to maintain their jobs in job situations that are always changing every moment. Employment skills are supported by student soft skills. A very important part of the soft skills of SMK graduates is the character of industrial work.

In the implementation of learning at SMK, students are not only given hard skills but are also required to have soft skills both in practice and theory in order to be able to work productively and with quality. Neff \& Citrin (2001) in Simatur (2014) said that the key to a person's success is determined by $90 \%$ 
soft skills and only $10 \%$ is determined by hard skills. A study by the Indonesian Ministry of National Education in 2009 also stated that $85 \%$ of one's success in education is determined by soft skills. Suryanto et al. (2014) said that in the business world or industry, soft skills that are relevant are among those needed by the business world or industries that are taught in Vocational High Schools include: honesty and good behavior, a sense of responsibility, time discipline, working safely, being tough / persistent at work, able to deal with stress, not depending on others, and easy to accept input.

One of the applications of soft skills is applying work character in theoretical and practical learning as well as in classrooms and workshops. The work system that is studied is "kaizen" which includes the 5R (Ringkas/Brief, Resik/Clean, Rawat/Careful, Rapi/Neat and Rajin/Diligent). The 5R concept is an effective method in creating an ideal work environment and has a major impact on the quality and productivity of an industry. The $5 \mathrm{R}$ concept can be used to build student self-confidence, the student responsibility for the work being done, discipline towards time, and to have work mental resilience in accordance with the needs of the workforce in the industry. The most important thing in applying the $5 \mathrm{R}$ concept is that it will increase the effectiveness of student learning and will reduce work accidents during learning. 5R implementation has been widely applied in workshops and classes so that students are able to comfortably and at the same time reduce the rate of work accidents. Learning in workshops and in classrooms has a lot of potential for causing work accidents to students. Work accidents are an important part of the implementation of Occupational Health and Safety (K3). Ismara \& Prianto (2017) said that implementing K3 is one of efforts to create a workplace that is safe, healthy, free from environmental pollution, so as to reduce and even free from work accidents and occupational diseases that can increase work efficiency and productivity. Work accidents not only cause casualties but also disrupt the overall production process.

\section{RESEARCH METHODOLOGY}

This research is a type of case study research using the explanatory mixed method-consequential method and carried out with the Countenance Stake evaluation model. There are 3 stages in the Countenance Stake evaluation model, namely input (antecedents), process (transactions) and output (outcomes). The antecedent's stages in this research are facilities and infrastructure, productive learning process and job readiness. The transaction stages in this study are student performance and the performance of subject teachers. and the last, the outcome stages in this study are knowledge obtained after students graduate and are ready to work in industry. This research was conducted at 4 Vocational High Schools (SMK) in April-May 2018.

The subjects of this research were Vocational High Schools (SMK) in Yogyakarta and Central Java that have the Electronics Industry expertise program in their schools. of DIY and Central Java. The sample of SMKs selected in this study were SMK N 2 Pengasih, SMK Muhammadiyah Prambanan, SMK N 7 Semarang, and SMK $\mathrm{N} 4$ Semarang. As a source of data (respondents) in this study were students both in class X and class XI of the Industrial Electronics expertise program. The samples were selected using purposive sampling technique.

The data collection techniques in this study were questionnaires, interviews and observations. Before the instruments contained in the questionnaire, interview sheets and observation sheets were given to students, the instruments were first tested for instrument validation with construct validity based on the consideration of two lecturers through expert judgment.

\section{FINDING AND DISCUSSION}

\section{Industry-Based Work Character Development in Teaching and Learning Activities at SMK}

Industry-based work character development in teaching and learning activities at SMK has been very good. Character building has been implemented in the lesson plan, in the syllabus and from habituation at school. The research results are described as follows:

\section{Antecedents Stage}

Based on the results of the questionnaire at the antecedent's stage, the development of work character in teaching and learning activities is in the very good category with an average value of 63.04 and the highest ideal value is 81 . When viewed from the statement items, the lowest results were obtained on the statement of using personal protective equipment while being practice with the score obtained from 112 students of 273. So far, when practicing, students do not use personal protective equipment such as when drilling does 
not use glasses and gloves, when dissolving PCB students do not use gloves and masks, and many more. This shows that teachers need to prepare personal protective equipment for students when carrying out practices so that there are no accidents due to work and also increase the habit of using personal protective equipment. The personal protective equipment includes hats, masks, goggles, masks, gloves, safety shoes, and work clothes or wear packs. Character values have been listed in the lesson plans and syllabus, but in fact there are still teachers who do not give examples to their students the use of personal protective equipment such as wear packs and safety shoes. This condition proves that teachers do not teach their students to work safely. In fact, working safely is very necessary in Business World and Industrial World (DUDI). Working safely can reduce the potential for work-related accidents to workers. Working safely also makes maximum work results. The highest results in the antecedent's aspect were found in the statement of the teacher of productive subjects before carrying out theoretical learning before carrying out practice with a score of 378 . That means, the teacher has provided learning in accordance with the previously prepared lesson plan (RPP). The teacher provides theoretical learning before practice, so that students understand better the material to be studied first.

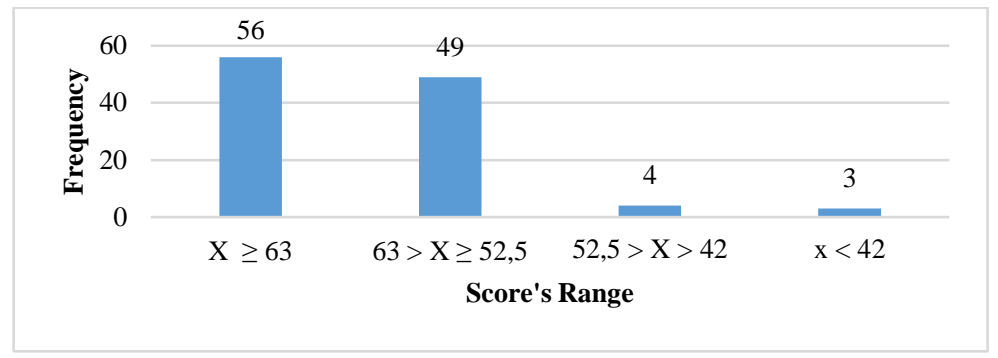

Figure 1. Distribution Diagram for Antecedents Data Results

Figure 1 shows that of the 112 respondents; 3 respondents are in the bad category, 4 respondents are in the poor category, 49 respondents are in the good category, and 56 respondents are in the very good category. Overall, work character development at the antecedent's stage was very good with a percentage of $75.05 \%$.

Table 1. NPK Value of Antecedents Stage

\begin{tabular}{|l|l|l|l|l|l|}
\hline $\begin{array}{l}\text { Total of } \\
\text { Respondents }\end{array}$ & $\begin{array}{l}\text { Total of } \\
\text { Statement }\end{array}$ & $\begin{array}{l}\text { Total } \\
\text { Score }\end{array}$ & NPK & $\begin{array}{l}\text { Percentage } \\
(\%)\end{array}$ & Information \\
\hline 112 & 21 & 7061 & 63,04 & 75,05 & Very good \\
\hline
\end{tabular}


Based on the results of interviews with the Head of the Industrial Electronics Expertise Program from 4 Vocational High Schools in this study, it was stated that for the antecedent's stage, the practice space and theoretical space were quite good and suitable for use, but for the area of the practice space was not large enough. The practical and theoretical rooms are also safe, comfortable and clean, in accordance with the Standard Operational (SOP) and K3. Practical equipment has been added according to needs and in accordance with technological developments and K3. The curriculum, lesson plans, and syllabus have also integrated work character in them.

Based on the results of teacher observations in the learning process, it shows that work character development has been carried out well. The teacher prepares the learning administration, one of which is lesson plan and syllabus. The lesson plan and the syllabus that include character values will be applied by students during the learning process. But in fact, during teaching learning process, there were still teachers who did not give an example to students by using wear packs and safety shoes during practical learning.

Based on the description that has been explained, it can be concluded that the development of work character in the teaching and learning process has been done well, but there is still something to pay attention to, regarding the use of personal protective equipment such as safety shoes and wear packs, so that students get used to protecting themselves while doing good practice at school as well as in the industry later and of course accustomed to applying the 5R concept.

\section{Transaction Stage}

Based on the results of the research questionnaire at the transaction stage, the fostering of work character in teaching and learning activities was in the very good category with an average score of 44.05 and the highest ideal score was 56 . When viewed from the statement items, the lowest results were obtained in the statements of students not cheating on friends' work with a score obtained from 112 students of 296. That means, students often cheat on a friend's work, both in the form of reports on practical results and others. This proves that soft skills depending on others for work are still low. The highest results on the transaction aspect are found in the statements of productive subject teachers assessing students' practical work with a score of 391 . That means, productive teachers always provide programmed assessments in accordance with the lesson plan that has been compiled.

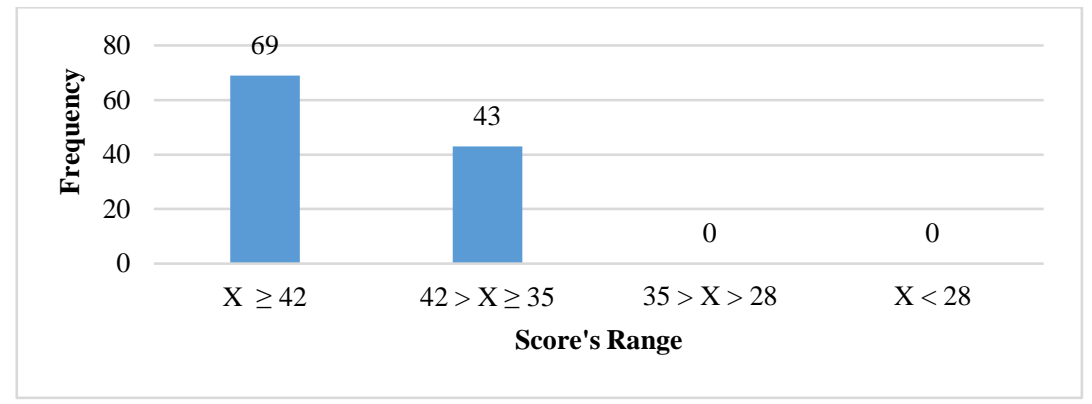

Figure 2. Frequency Distribution Diagram of Transaction Data Results

Figure 2 shows that of the 112 respondents, there were no respondents who were in the bad and quiet bad categories, 43 respondents were in the good category, and 69 respondents were in the very good category. Overall, work character development at the transaction stage is very good with a percentage of $78.67 \%$.

Table 2. NPK Value on Transaction Stage

\begin{tabular}{|l|l|l|l|l|l|}
\hline $\begin{array}{l}\text { Total of } \\
\text { Respondents }\end{array}$ & $\begin{array}{l}\text { Total of } \\
\text { Statement }\end{array}$ & $\begin{array}{l}\text { Total } \\
\text { Score }\end{array}$ & NPK & $\begin{array}{l}\text { Percentage } \\
(\%)\end{array}$ & Information \\
\hline 112 & 14 & 4934 & 44,05 & 78,67 & Very good \\
\hline
\end{tabular}

Based on the results of interviews with the Head of the Industrial Electronics Expertise Program from four Vocational High Schools in this study, it was stated that for the transaction stage, the development 
of work character that has been running so far, includes in teaching learning process. In addition, work character development has also been implemented since students are admitted to school or during student orientation (MOS) where the school invites the police, military, and health officer to guide students.

The indicators of success of fostering work character in schools are that students have characters such as orderly, have responsibility, cooperation, discipline, respect for teachers and friends, religiosity, tolerance, hard work, initiative, honesty, and many more where everything is included in the attitude value of lesson plan. During the ceremony on Monday, students who are late will stand in front of the gate until the ceremony is over and will be given sanctions in the form of reprimand and scoring.

At SMK N 2 Pengasih, students who are late or students who are disorganized when participating in the ceremony will be sanctioned to run around the field 3 times, or if the student is unable to run, the student must clean the school environment for 15 minutes. In 4 schools of this study, character building is also applied when schools hold community service or social services to orphanages, hold fast breaking together during the month of Ramadan every year.

During Internship Activities (PI), there are student personality values in the list of industrial work practice values, such as honesty, discipline, cooperation, initiative and responsibility. The factors that support the implementation of this work character development are internal factors and external factors.

The most influential external factors are family factors (lack of facilities from the family, home away from school, lack of motivation from the family); as well as school environmental factors (there are regulations in the school canteen regarding the placement of plates or cups after use); facilities and infrastructure factors (absence of a lab sheet or job sheet during practice, inadequate equipment according to the number of students); teacher and student factors themselves (teachers do not use personal protective equipment when practicing / not working safely, students do not understand the meaning of character for themselves). Meanwhile, internal factors that influence work character development are honesty, time discipline, responsibility, enthusiasm, and mutual respect.

Based on the results of teacher observations in the learning process, it shows that work character development has been carried out starting from the opening activity to the closing activity. In the opening activity, the teacher inserts character building from activities or events that occur around them.

At SMK N 4 Semarang, religious character development starts from the starting hours of learning by reading the letters Al-Fatihah and Asmaul Husna to completion. Religious character is applied in all four Vocational High Schools by praying on time. While teaching learning process is conducted, and then there is a call to prayer, learning must stop, students and teachers pray together at the school mosque. The teacher also demonstrated the practical tools but not the K3, because the teacher did not use wear packs and safety shoes when the practice learning. At SMK Muhammadiyah Prambanan, character building on discipline and on time is not implemented. Based on the observation, some students enter the practice room half an hour after learning hours have started, even though the teacher has arrived on time and is waiting for students, but there is no penalty for students who are not disciplined and not on time.

Based on the description that has been explained, it can be concluded that the development of work character in vocational students has been instilled since the student entered the vocational school or during the Student Orientation Period (MOS). It is necessary to make strict rules and sanctions regarding the attitudes of students or teachers who are less disciplined and not on time in attending the class.

\section{Outcomes Stage}

Based on the data from the questionnaire that has been obtained from four Vocational High Schools in two provinces (Yogyakarta and Central Java), it can be concluded that the outcomes stage is in the very good category with an average score of 29.33 and the highest ideal score is 36 . The lowest result was the student's statement that is "Students dare to open new businesses to open up jobs in the field of Industrial Electronics" with a score of 322 for 112 students.

That means that students are not yet sure of their abilities related to the Industrial Electronics expertise program. There is a need for further development regarding character in students and development regarding life after completing education at SMK. The highest result on the aspect of outcomes is found in the statement of working not to differentiate between coworkers with a score of 386. That means, solidarity between students is very high because students do not differentiate between their friends in studying because they realize that they both need knowledge. 


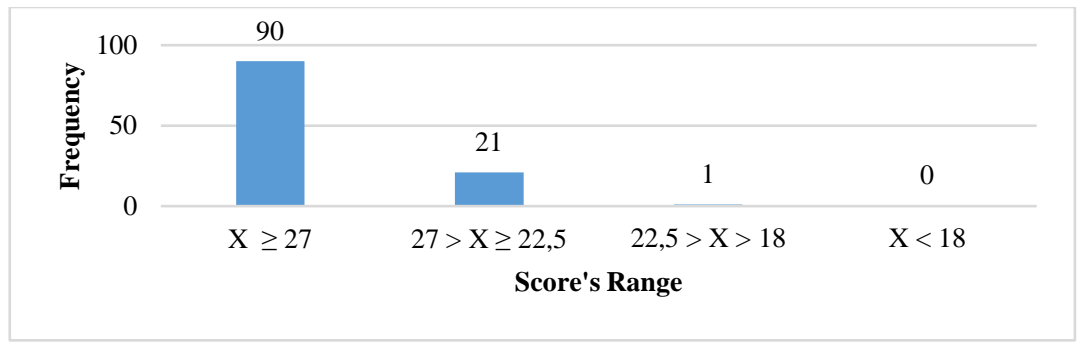

Figure 3. Distribution Diagram of the Frequency of Outcomes Data

Figure 3 shows that of the 112 respondents, there are no respondents who are in the unfavorable category, 1 respondent is in the poor category, 21 respondents are in the good category, and 90 respondents are in the very good category. Overall, work character development at the outcomes stage is very good with a percentage of $81.47 \%$.

Table 3. NPK Outcomes Stage Value

\begin{tabular}{|l|l|l|l|l|l|}
\hline $\begin{array}{l}\text { Total of } \\
\text { Respondents }\end{array}$ & $\begin{array}{l}\text { Total of } \\
\text { Statement }\end{array}$ & $\begin{array}{l}\text { Total } \\
\text { Score }\end{array}$ & NPK & $\begin{array}{l}\text { Percentage } \\
(\%)\end{array}$ & Information \\
\hline 112 & 9 & 3285 & 29,33 & 81,47 & Very good \\
\hline
\end{tabular}

Based on the results of interviews with the Head of the Industrial Electronics Expertise Program from four vocational schools in this study, it was stated that for the outcomes stage, students had sufficient work character and high discipline. In addition, 3 out of 4 schools also have their own Special Job Fair (BKK) and have collaborated with various industries to carry out internship (PI) or student recruitment in the industry. When viewed from the percentage of graduates, many graduates from the Industrial Electronics Expertise Program are working, but only some are in accordance with their majors. At SMK N 7 Semarang, every year there are always students who get educational scholarships and work in Japan (GAEC) and Germany (AUSBILDUNG). At SMK N 2 Pengasih, there is also an internship program in Japan.

Based on the results of teacher observations in the learning process, it shows that in theoretical and practical learning, students have implemented work characters such as religion, cooperation, honesty, hard work, discipline and responsibility. During learning process, assessments are held programmatically, such as presentations on the results of discussions, practice reports, evaluation of practical learning, and many more.

Based on the description that has been explained, it can be concluded that students already have work characteristics ranging from religious, disciplined, responsibility, honest, hard work, punctual, cooperation. This work character already reflects the work character culture that will be needed when students enter the business / industry world. For work readiness, students prefer to work rather than open new businesses to open up jobs in the field of Industrial Electronics.

\section{Factors Affecting Industry-Based Work Character Development}

The factors that influence industry-based work character development include:

\section{External Factors}

\section{Family Factors}

The family factor is the most important and most influential factor in fostering work character, because it is from this family environment that these students get knowledge for the first time. Unattended family facilities, homes far from school, less motivation from family, mediocre family economic conditions make students difficult and less enthusiastic in the teaching and learning process.

\section{School Environmental Factors}

One of the school environmental factors that influence the development of work character is the school canteen environment. The school canteen which accustoms students, after eating or drinking, to put the cutlery back into the shelf that has been provided, will make students more disciplined and cleaner in a job. 


\section{Facility and Infrastructure Factors}

The absence of a lab sheet or job sheet when practice, becomes a factor inhibiting student readiness in learning. The teacher should prepare a lab sheet or job sheet before carrying out the practice, so that students do not get confused while practicing and also, they will use of personal protective equipment too.

\section{The Teacher and Student Factors themselves}

During learning process, the teacher does not give an example to students by using personal protective equipment such as wear packs and safety shoes. Indirectly, the teacher gives an example to students not to work safely. In addition, students also do not understand the importance of character for themselves. So that there are still those who still ignore the discipline of time.

\section{Internal Factors}

Internal factors that influence work character development are religion, honesty, time discipline, responsibility, creative, innovative, tough, hard work, enthusiasm and mutual respect.

\section{CONCLUSION}

The conclusions of the research that has been carried out are as follows: (1) Fostering of work character in the four vocational high school during teaching and learning process is in the very good category. Judging from the description of the antecedent data, the results of the student questionnaire showed that the mean score for the antecedent data was 63.04. The lowest score from the 112 students' questionnaire for antecedent's data was 273 with a statement of 'using personal protective equipment (PPE) while practicing learning. Judging from the description of data transactions, the results of the student questionnaire showed that the average value for data transactions was 44.05 . The lowest score from the 112 students 'questionnaire for data transactions was 296 with the statement that students did not copy their friends' work. Judging from the outcomes data, the results of the student questionnaire showed that the mean score for the outcomes data was 29.33. The lowest score from the 112 students' questionnaire for the output data was 322 with the statement that the students dared to open new businesses to open jobs in the field of Industrial Electronics; (2) The factors that support the development of work character include religion, honesty, time discipline, responsibility, creative, innovative, tough, hard work, enthusiasm and mutual respect.

\section{REFERENCE}

BPS. (2019). Keadaan Tenaga Kerja Indonesia Agustus 2020. Jakarta: Badan Pusat Statistik.

Hanafi, I. (2012). Re-orientasi keterampilan kerja lulusan pendidikan kejuruan. Jurnal Pendidikan Vokasi, 2(1). Ismara, I., \& Prianto, E. (2017). Bagaimanakah agar Laboratorium dan Bengkel Pendidikan Vokasi menjadi NYAMAN, SELAMAT, dan SEHAT. Yogyakarta: UNY Press.

Neff, T. J., \& Citrin, J. M. (2001). Lesson from The Top. New York: Doubleday Business.

Simatur, Z. (2014). Babon Psikotes Paling Update. Jakarta: Visimedia.

Suryanto, D., Kamdi, W., \& Sutrisno, S. (2014). Relevansi soft skill yang dibutuhkan dunia usaha/industri dengan yang dibelajarkan di Sekolah Menengah Kejuruan. Teknologi Dan Kejuruan: Jurnal Teknologi, Kejuruan Dan Pengajarannya, 36(2).

Wibowo, N. (2016). Upaya memperkecil kesenjangan kompetensi lulusan sekolah menengah kejuruan dengan tuntutan dunia industri. Jurnal Pendidikan Teknologi Dan Kejuruan, 23(1), 45-59. 